\title{
On the physical oceanography of the Kattegat and Clyde Sea area, 1996-98, as background to ecophysiological studies on the planktonic crustacean, Meganyctiphanes norvegica (Euphausiacea)
}

Received: 2 February 1999 / Accepted: 6 April 1999

\begin{abstract}
The euphausiid, Meganyctiphanes norvegica (M. Sars), has an extremely wide distribution around the North Atlantic, from Canada to the Arctic to the western Mediterranean. It appears to be adaptable to life under quite different oceanographic conditions, yet no morphological features have been identified that distinguish any of the populations occurring in different areas between which exchange must be supposed to be restricted. The genetic, physiological, behavioural and ecological investigations that are being carried out on M. norvegica in the Kattegat, the Clyde Sea area and the Ligurian Sea (the EU MAST III PEP Project) in order to study its adaptability must be closely related to the physical environment within which the respective populations occur. This paper presents a summary of the hydrographic conditions found in the Kattegat and the Clyde Sea area in summer and in winter, during each research cruise, and places them in the context of current understanding of the hydrography in each area. An account of the hydrography of the Ligurian Sea is in preparation (Dallot et al., in preparation). The data will be used in the further analysis of genetic, physiological and behavioural adaptability of $M$. norvegica, and will be available for use as appropriate to supplement other hydrographic studies in the regions concerned.
\end{abstract}

Key words Meganyctiphanes norvegica $\cdot$ Kattegat . Clyde Sea $\cdot$ Hydrographic conditions $\cdot$ Adaptability

F. Buchholz (®) $\cdot$ R. Saborowski

Biologische Anstalt Helgoland, AWI, Meeresstation, D-27498 Helgoland, Germany

e-mail: fbuchholz@ awi-bremerhaven.de

J.B.L. Matthews · G.A. Tarling

Scottish Association for Marine Science, P.O. Box 3,

Oban, Argyll, A34 4AD, UK

S. Dallot · J.P. Labat

Observatoire Océanologique, LOBEPM

Océanographie biochimique et Ecologie

BP 28, F-06230 Villefranche sur mer. France

\section{Introduction}

The project, Impact of a Climatic Gradient on the Physiological Ecology of a Pelagic Crustacean (PEP) is a component of the EU MAST III Programme. It is a study of functional marine biodiversity as a basis for understanding ecosystem structure, dynamics and resilience. It concentrates on a single species, the euphausiid Meganyctiphanes norvegica, as a pelagic model in zooplankton. $M$. norvegica is an important component of the plankton over an extraordinarily wide area in the North Atlantic living under very different hydrographic conditions. Its physiological, behavioural and genetic diversity is being investigated in relation to environmental conditions, particularly the thermal and trophic regimes, at specific locations in the Clyde Sea area in Scotland, the Kattegat and the western Mediterranean.

The different climatic conditions at the three locations provide the basis for a "natural experiment" intended to determine the capacity of $M$. norvegica to cope with short- and long-term changes in sea temperature. Furthermore, during its vertical migration, the animals cross different water masses in each of the three areas. The influence of the different abiotic and biotic conditions on the physiology of the migrating animals is analysed, in order to identify causes and effects of this characteristic behaviour.

Knowledge of the physical environment in all three areas underpins all the biological investigations, and a thorough hydrographic survey has therefore been maintained throughout each of the seven cruises, two to the Clyde Sea area and the Ligurian Sea, and three to the Kattegat. This paper presents a summary of the data from the Kattegat and the Clyde Sea area that relate particularly to the biological sampling and places them in the context of previous hydrographic knowledge of each area, in order to provide a common hydrographic background for subsequent papers dealing with the various biological aspects of the PEP project. 
Fig. 1 Map of the Kattegat and surrounding area, showing the main sampling site in the Alkor Deep, and the main surface currents (from Svansson 1975)

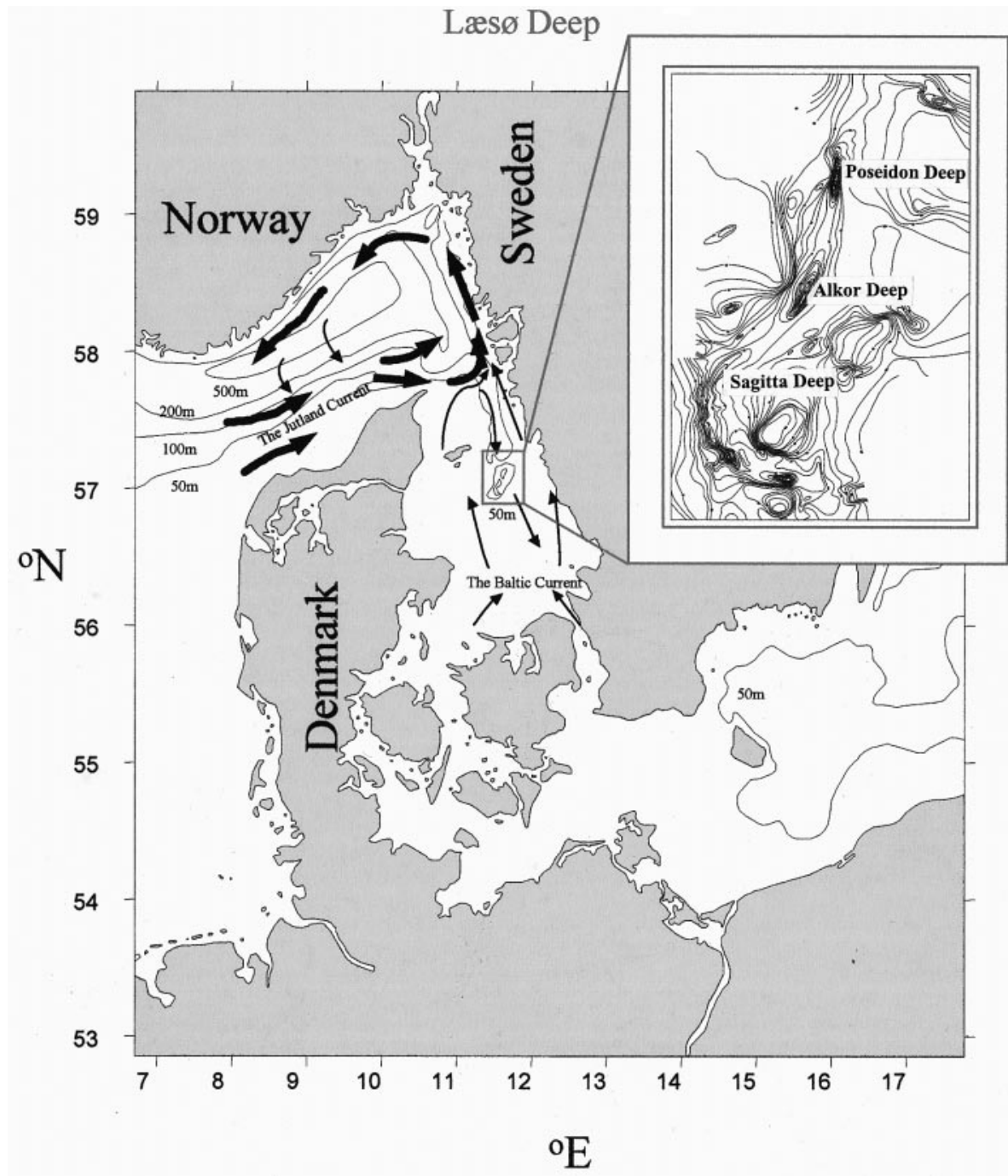

Table 1 List of cruises within the PEP program to the Kattegat and the Clyde Sea

\begin{tabular}{|c|c|c|}
\hline Cruise name & Dates & Locality \\
\hline SCOTEX I & 3-10 July 1996 & $\begin{array}{l}\text { Clyde Sea area, } \\
\text { W Scotland }\end{array}$ \\
\hline KATTEX I & 15-31 July 1996 & $\begin{array}{l}\text { Kattegat, east of Læs } \varnothing \text {, } \\
\text { Denmark }\end{array}$ \\
\hline SCOTEX II & 15-27 February 1997 & $\begin{array}{l}\text { Clyde Sea area, } \\
\text { W. Scotland }\end{array}$ \\
\hline KATTEX II & 5-18 March 1997 & $\begin{array}{l}\text { Kattegat, east of Læs } \varnothing \text {, } \\
\text { Denmark }\end{array}$ \\
\hline KATTEX III & 22 July-5 August 1998 & $\begin{array}{l}\text { Kattegat, east of Læs } \varnothing \text {, } \\
\text { Denmark }\end{array}$ \\
\hline
\end{tabular}

\section{Materials and methods}

The new data presented in this paper were all obtained during the five PEP cruises to the two areas, on board FS Heincke operated by the Biologische Anstalt Helgoland (Table 1). Meteorological data were collected from the weather station operated on board RV Heincke, except for SCOTEX II when there was a failure of data storage after 2 days. Hydrographic observations were carried out throughout each cruise using the conductivity and temperature sensors mounted on the $9 \times 1 \mathrm{~m}^{2}$ Multiple Opening/Closing Net and Environmental Sensing System (MOCNESS), manufactured by BESS, Falmouth, Massachusetts, USA (Wiebe et al. 1985), which was the principal net used to sample $M$. norvegica and other zooplankton. The complete data set is stored in the PEP data archive and is summarized in this paper. Other hydrographic data were collected by means of CTD instruments and are also stored in the PEP data archive but are not presented here.

A $150-\mathrm{kHz}$ narrow-band Acoustic Doppler Current Profiler (RD Instruments, San Diego, California, USA), mounted in the oceanographic well of the research vessel, was used to obtain current measurements (direction and speed) at predetermined depth horizons through the water column. The data were automatically averaged for each 8-m "depth bin" to provide sufficiently accurate current data $\left( \pm 0.6 \mathrm{~cm} \cdot \mathrm{s}^{-1}\right)$ at set points in the water column.

\section{Kattegat}

The Kattegat (Fig. 1), the channel some 100-150 km wide that lies between the east coast of Jutland, Denmark, and the southwest coast of Sweden, forms the major hydrographic transition zone between the Baltic Sea and the North Sea. To the north lies the Skagerrak within 


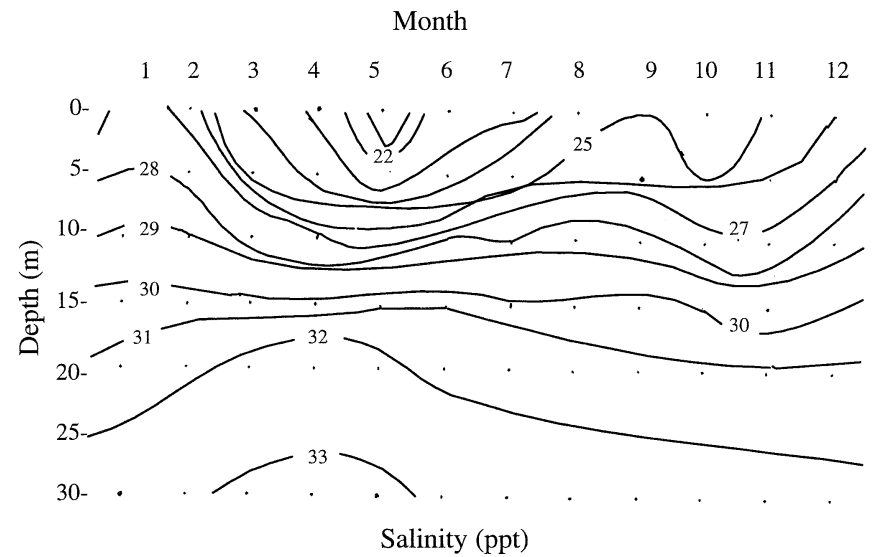

Fig. 2 Long-term monthly means of salinity measured at LV Læsø Trindel (from Svansson 1975)

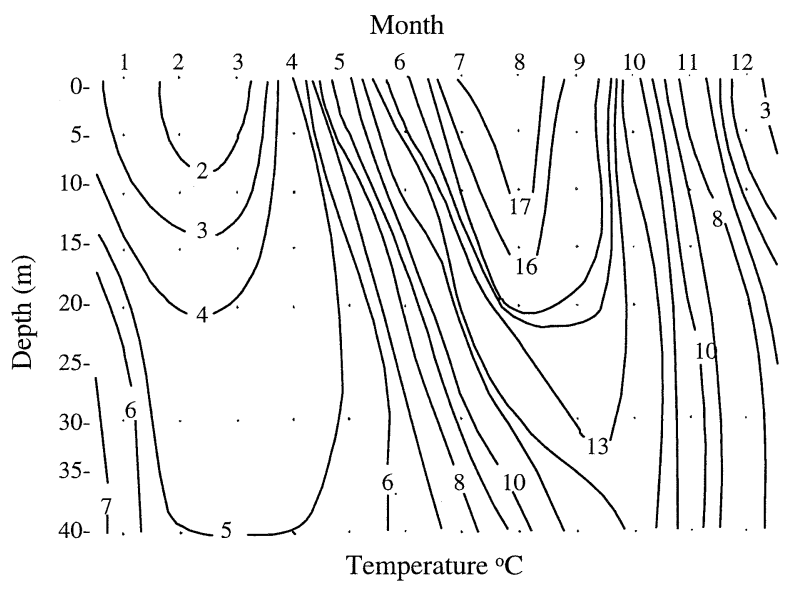

Fig. 3 Long-term monthly means of temperature measured at LV Fladen (from Svansson 1975)

which there is cyclonic circulation of North Sea water and through which flows the Baltic Current, northwards along the west coast of Sweden, before being deflected southwestwards as the Norwegian Coastal Current and becoming ever more marine as North Sea water becomes entrained in the flow (see Gustafsson and Stigebrandt 1996) for a recent review of circulation in the Skagerrak, with particular emphasis on the distribution of fresh water). To the south lie the Belt Sea and the Øresund which surround the Danish archipelago and provide several narrow channels through which water can flow, mainly from the Baltic Sea.

The Kattegat has been the focus of much study for practical and scientific reasons. It is highly productive, hence a keen fishery interest in the area, but it is also subject to a range of anthropogenic influences. Eutrophication, pollution and hypoxia, resulting from industrial and agricultural sources at both ends, have attracted much attention, e.g. the Baltic Entrance Project (see Svansson 1984), the Joint North Sea D(ata) A(cquisition) $\mathrm{P}$ (roject) and the Skagerrak Experiment (Danielssen et
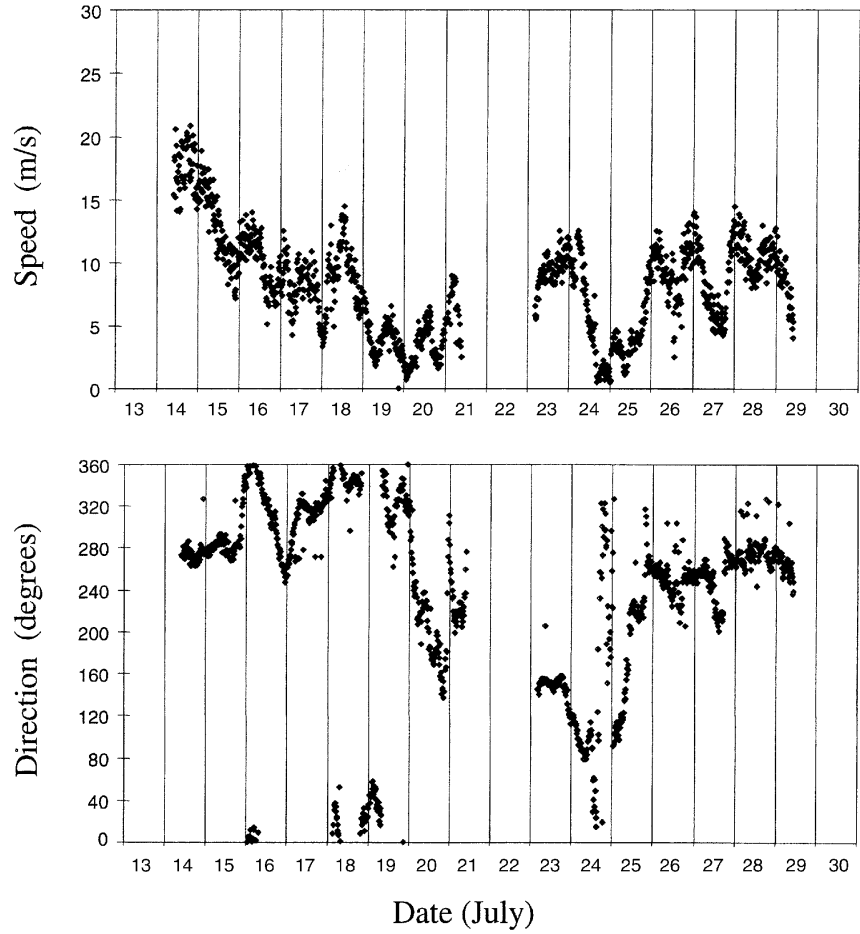

Fig. 4 Wind speed and direction over the Alkor Deep during KATTEX I

al. 1991). The confluence of two water masses with strongly contrasting properties in a constrained and welldefined area has stimulated the study and modelling of turbulence and exchange processes (Stigebrandt 1980, 1983; Svansson 1980).

The mean depth of the Kattegat is $23 \mathrm{~m}$ (Svansson 1984) but a deep channel runs approximately north-south nearer the eastern (Swedish) side, connecting with the deep water of the Skagerrak and becoming progressively shallower as it continues southwards. It ends with a sill some $50 \mathrm{~m}$ deep and $25 \mathrm{~km}$ wide at approximately $57^{\circ} 30^{\prime} \mathrm{N}$. Northeast of the island of Læs $\varnothing$, the Kattegat Channel begins at $57^{\circ} 21^{\prime} \mathrm{N}$ with a depth of over $80 \mathrm{~m}$ and continues in south-south-westerly to southeasterly directions for $45 \mathrm{~km}$. The channel is characterized by a series of deeper, elongated basins of which the four deepest ones (134-151 m) are situated in the northern half. The most extensive of these is the Alkor Deep, some $3.5 \mathrm{~km}$ long and $1 \mathrm{~km}$ wide with a maximum depth of $134 \mathrm{~m}$, which runs in a NNE-SSW direction. The surrounding area of the Kattegat Channel is $20-40 \mathrm{~m}$ deep. This topography is not discernible on current sea charts and was described in detail by Ulrich (1983) and, with large-scale bathymetric charts, by Ulrich and Eisele (1993). The Kattegat Channel appears to be of glacial origin. The sediments are silt or silty sand and are always well oxygenated by currents up to $35 \mathrm{~cm} \cdot \mathrm{s}^{-1}$ (Alkor Deep) which prevent stagnant conditions from developing (Ulrich and Eisele 1993, unpublished observations).

Water circulation (see Fig. 1) is dominated by (1) the northward flow of the Baltic Current, low-salinity water 


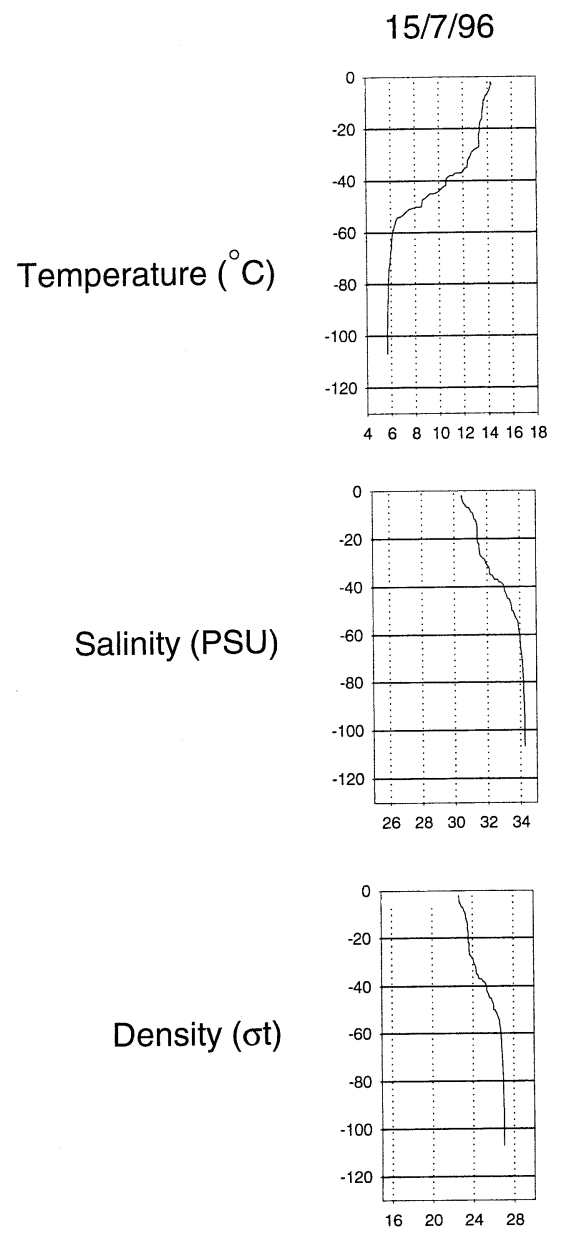

Fig. 5 Temperature, salinity and density profiles in the Alkor Deep during KATTEX I

(20-27 PSU, lowest in the late spring and early summer) with seasonally changing temperature (from $<2^{\circ} \mathrm{C}$ in February to $>17^{\circ} \mathrm{C}$ in August) and (2) an underlying countercurrent of North Sea water with higher salinity (30-34 PSU) and an annual temperature range of only $5-6^{\circ} \mathrm{C}$, i.e. between 5 and $10^{\circ} \mathrm{C}$ (Figs. 2, 3). While the inflow of deep water to the Kattegat occurs to the east of Læs $\varnothing$, the outflow of surface water from the Baltic seems to be dominated by the flow west of Læs $\varnothing$ (Andersson and Rydberg 1993). The main pycnocline, which is permanently maintained by the salinity gradient and enhanced by the steep temperature gradient in the summer, usually occurs at approximately $15 \mathrm{~m}$. Below about 80 $\mathrm{m}$, salinity is stable at about 35 PSU (Buchholz and Boysen-Ennen 1988), indicating no mixing with Baltic water in the basins, including the Alkor Deep (see Svansson $1975,1980,1984$ for more details of the hydrography of the area).

Seasonal hydrographic changes are mainly the result of variation in the quantity and temperature of the Baltic Current, local insolation, and the strength of the inflow from the Jutland Current. The inflow of high-salinity water (>33 PSU) in winter has been estimated at 64,000 $\mathrm{m}^{3} \cdot \mathrm{s}^{-1}$, compared with only $28,000 \mathrm{~m}^{3} \cdot \mathrm{s}^{-1}$ in summer
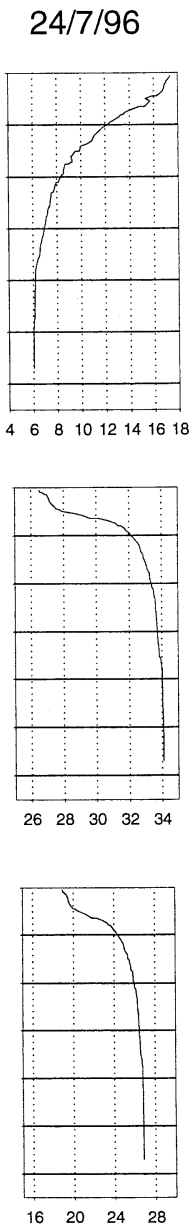

$26 / 7 / 96$

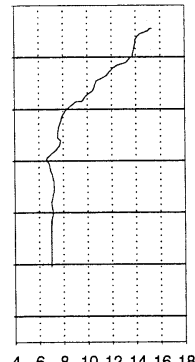

$\begin{array}{llllllll}4 & 6 & 8 & 10 & 12 & 1416 & 18\end{array}$
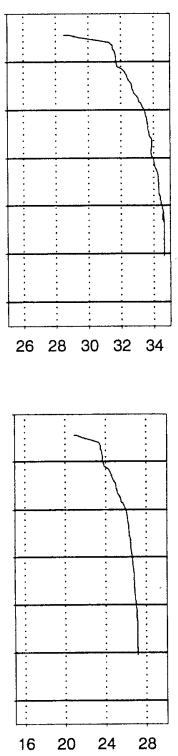

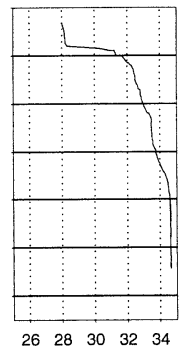

$28 / 7 / 96$

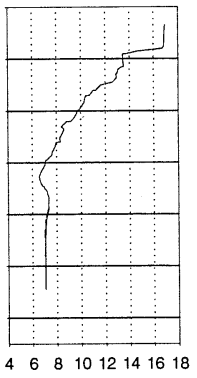

$\widehat{\hat{\xi}}$
$\frac{F}{\hat{0}}$
ه

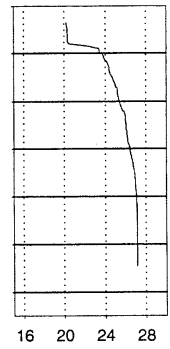

(Andersson and Rydberg 1993). Periods of strong wind can cause marked short-term changes: winds from the south strengthen the Baltic Current and the corresponding countercurrent, and so enhance circulation and mixing; winds from the north retard the Baltic Current and result in diminished circulation. Below the halocline, salinities tend to be highest during the windy months of October and November (Buchholz and Boysen-Ennen 1988).

Previous observations indicate that oxygen concentrations are consistently at or near saturation in the surface and middle layers of the Kattegat. Since such levels do not impose any physiological constraints on the behaviour or distribution of $M$. norvegica, more detailed oxygen data are not presented here. In the bottom water of the Alkor Deep, however, oxygen levels may be slightly depressed. At 100-120 m, for example, Boysen and Buchholz (1984) recorded 84\% in March and 74\% in July 1981, Vetter and Buchholz (1997) recorded 83\% in July 1994, and 73\% saturation was recorded in July 1995 (Buchholz, unpublished).

\section{KATTEX I, 15-31 July 1996}

Wind conditions are shown in Fig. 4. During the first 3 days of the cruise, wind was westerly to northerly, ini- 


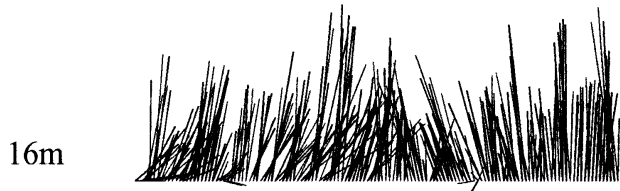

$48 \mathrm{~m}$

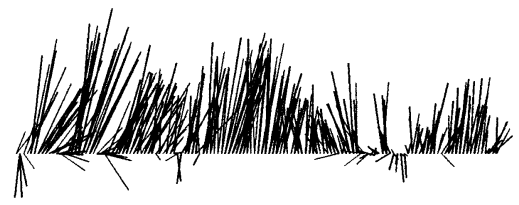

$80 \mathrm{~m}$

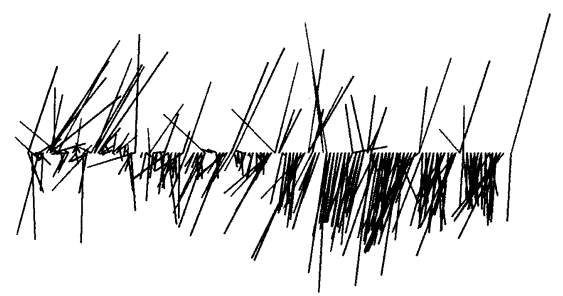

$30 \mathrm{~cm} / \mathrm{s}$
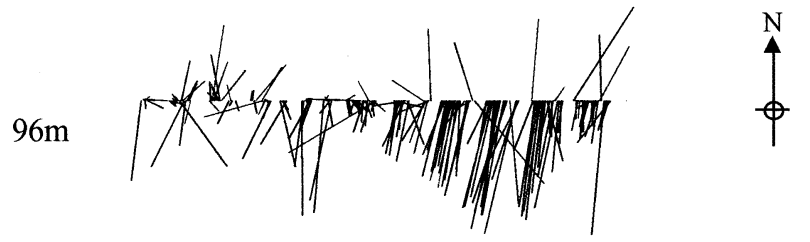

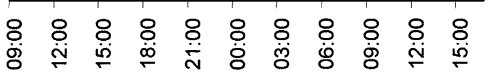

Fig. 6 Current speed and direction at four depths in the Alkor Deep during KATTEX I (18-19 July 1996)

tially at $20 \mathrm{~m} \cdot \mathrm{s}^{-1}$ but gradually decreased to about $5 \mathrm{~m} \cdot \mathrm{s}^{-1}$ by 19 July. At the same time the wind became more southerly and variable. For the last 5 days the wind returned to the west at $5-10 \mathrm{~m} \cdot \mathrm{s}^{-1}$, with a circadian pattern, tending to freshen in the evening and decrease during the day.

The hydrographic data are summarized in Fig. 5. The temperature profiles indicate a three-layered structure consisting of a rather changeable surface and intermediate layers and a nearly constant and isothermal deep layer. To start with, surface water was well mixed down to a depth of about $20 \mathrm{~m}$. Surface warming became apparent on $20 \mathrm{July}$, from 14 to $17^{\circ} \mathrm{C}$; at the same time, the thermocline became much sharper, the temperature dropping from 14 to $7^{\circ} \mathrm{C}$ between 30 and $40 \mathrm{~m}$ depth, where previously this drop had occurred over a distance of $35 \mathrm{~m}$, i.e.
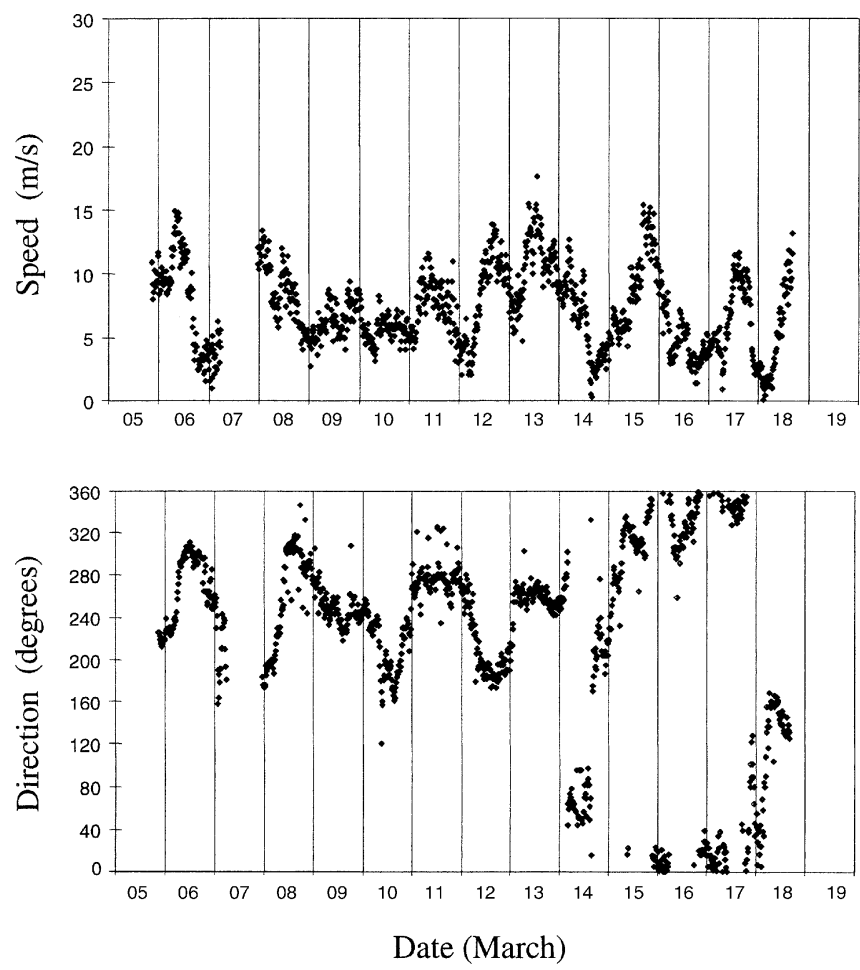

Fig. 7 Wind speed and direction over the Alkor Deep during KATTEX II

between 20 and $55 \mathrm{~m}$ depth. Although the surface temperature remained about $17^{\circ} \mathrm{C}$, a 15 -m-deep surface layer re-established itself towards the end of the cruise (28 July), the transition layer came to extend from 15 to $60 \mathrm{~m}$ and even below this the temperature of the deep layer rose slightly.

There was a similar three-layered structure in the salinity profiles, the main contrast being little indication on 20 July of a narrowing of the halocline around $35 \mathrm{~m}$; instead, salinity increased fairly smoothly throughout the surface and middle layers. Steep gradients usually occurred in the uppermost $10 \mathrm{~m}$ but this could be depressed to $15-20 \mathrm{~m}$ (18 and 28 July) following windy conditions. The salinity of the deep water increased as it warmed slightly towards the end of the cruise, evidence of continuing inflow of high salinity water that had also been subject to seasonal warming.

The density profiles show that there was little in the way of a sharp pycnocline to provide a barrier to the movement or exchange of organisms between layers, except after windy conditions when the near-surface water was thoroughly mixed to a depth of 15-20 m.

The measurements made on KATTEX I confirm previous observations that oxygen concentrations are consistently at or near saturation in the surface and middle layers. Within the Alkor Deep, however, they were slightly depressed, at around $77 \%$ between 100 and $120 \mathrm{~m}$ depth, in line with previous observations.

Figure 6 illustrates the direction and strength of currents at four depths. There were three general patterns 


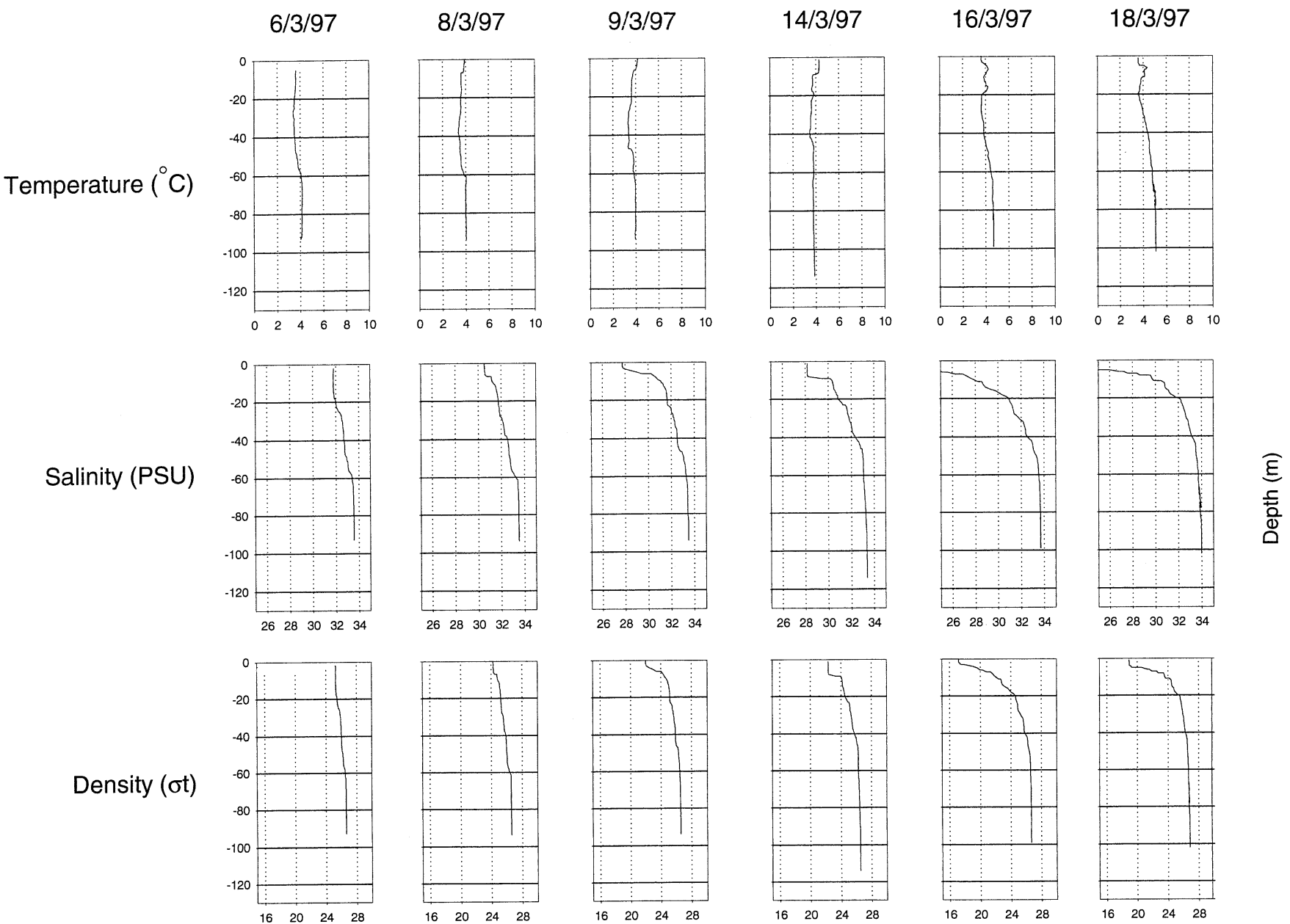

Fig. 8 Temperature, salinity and density profiles in the Alkor Deep during KATTEX II

corresponding to the three layers identified in the temperature and salinity plots. Near-surface currents $(16 \mathrm{~m})$ varied between north and northeast at 5 to $15 \mathrm{~cm} \cdot \mathrm{s}^{-1}$. In the middle layer $(40 \mathrm{~m})$, currents were weaker ( 5 to 10 $\mathrm{cm} \cdot \mathrm{s}^{-1}$ ) and more variable in direction, and there seemed to be a certain degree of tidal influence; for instance, between 15:00 h and 21:00 h on 18 July, during the flood tide, currents were easterly, whereas between 09:00 h and 15:00 h on 19 July, during the ebb tide, currents varied between NW and SW. Currents at $80 \mathrm{~m}$ were generally southerly to south-southwesterly in the range of $15-20 \mathrm{~cm} \cdot \mathrm{s}^{-1}$.

\section{KATTEX II, 5-18 March 1997}

Wind conditions are shown in Fig. 7. For the first 2 days the general direction was north of westerly with an intermittent speed of ca. $12 \mathrm{~m} \cdot \mathrm{s}^{-1}$. This shifted more to the southwest for a time on 10 March and dropped slightly. For the last half of the cruise (12-19 March) the wind was quite variable, between 0 and $15 \mathrm{~m} \cdot \mathrm{s}^{-1}$, and more northerly, even easterly, towards the end of the cruise. Hydrographic profiles are presented in Fig. 8. During the whole cruise, temperatures were close to $4^{\circ} \mathrm{C}$ throughout the water column, though there was a slight but consistent rise in temperature in the deep water during the last 3 days, at the same time as the surface water became more changeable. On the other hand, salinities at the start of the cruise were generally higher than they had been in summer between 0 and $30 \mathrm{~m}$ (30.4 as opposed to $29.1 \mathrm{PSU}$ at $4 \mathrm{~m}$ in summer), but lower than in summer below $30 \mathrm{~m}$ ( 33.5 as opposed to $34.2 \mathrm{PSU}$ at $90 \mathrm{~m}$ in summer); this indicates a greater degree of mixing between Baltic and North Sea inflow during the winter months. Nevertheless, there was still a three-layered pattern as observed during summer, with constant conditions near the surface and the bottom, and a transition layer in between. Surface conditions changed suddenly by 9 March when the salinity in the uppermost $5 \mathrm{~m}$ dropped to below 28 PSU. By 18 March it had dropped to below 24 PSU and there were signs of dilution down to at least $30 \mathrm{~m}$. Since the temperature range through the water column was small, density was largely a function of salinity and no independent effect of the pycnocline is likely.

The measurements made on KATTEX II also agree with previous observations that oxygen concentrations are consistently at or near saturation in the surface and 

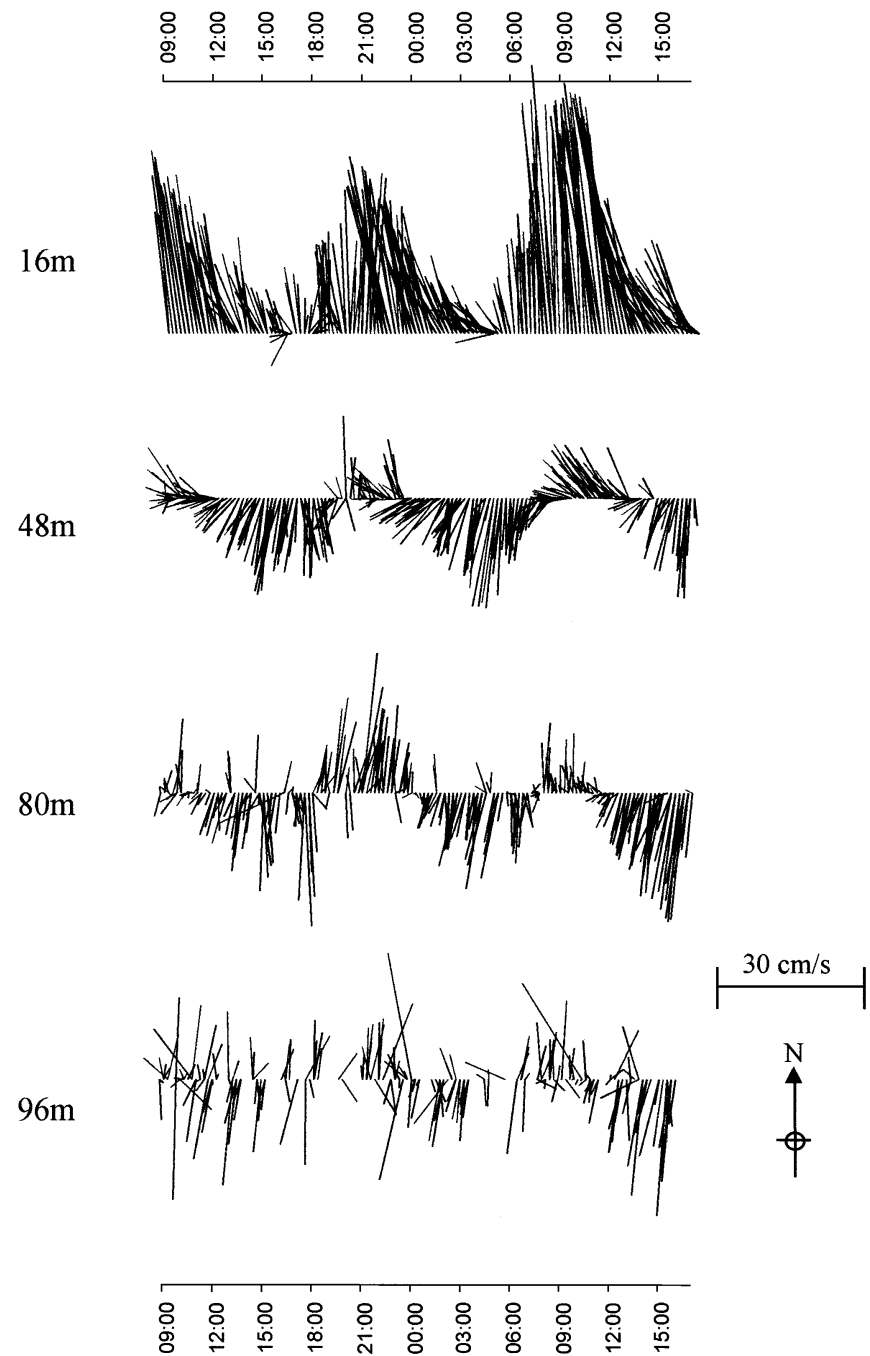

Fig. 9 Current speed and direction at four depths in the Alkor Deep during KATTEX II (8-9 March 1997)

middle layers. Even at 100 and $120 \mathrm{~m}$ depth within the Alkor Deep they were as high as $91 \%$ saturation.

Figure 9 illustrates the direction and strength of currents at four depths. Near the surface $(16 \mathrm{~m})$ they were north to northwest between 15 and $30 \mathrm{~cm} \cdot \mathrm{s}^{-1}$ but with a strong tidal influence. The middle layer (at $40 \mathrm{~m}$ ) exhibited currents that were generally southerly but tending to reverse for short periods when the surface current was at its strongest, corresponding to the ebb tide. This pattern, though weaker, could still be discerned at $80 \mathrm{~m}$ but at $96 \mathrm{~m}$ they were quite variable and usually quite weak.

\section{KATTEX III, 21 July - 4 August 1998}

Figure 10 illustrates the direction and strength of the wind. For the first 4 and the last 5 days of the cruise the wind was west to southwest, mostly between 5 and $15 \mathrm{~m} \cdot \mathrm{s}^{-1}$, though it briefly backed southerly on 23 July. Conditions were quite different on 28-29 July when the
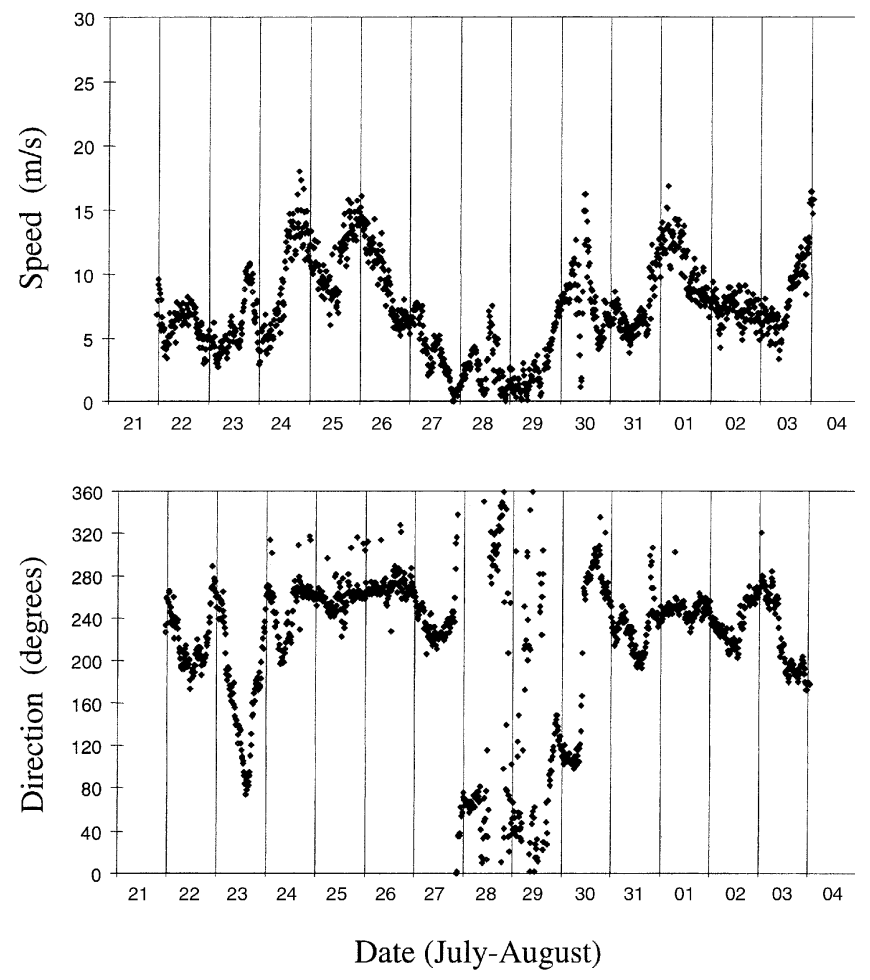

Fig. 10 Wind speed and direction over the Alkor Deep during KATTEX III

direction became quite variable but predominantly northeasterly and wind speed dropped to less than $3 \mathrm{~m} \cdot \mathrm{s}^{-1}$.

Figure 11 depicts the hydrographic conditions during the period. Surface temperatures were slightly in excess of $16^{\circ} \mathrm{C}$ and bottom water, below $80 \mathrm{~m}$, was at about $6.5^{\circ} \mathrm{C}$, but the detailed profile between 5 and $50 \mathrm{~m}$ was rather variable. Early on there was a distinct thermocline at about $40 \mathrm{~m}$ which rose by 24 July to near $30 \mathrm{~m}$ at the same time as a subsurface thermocline developed at 5-10 m. The double thermocline gradually weakened, resulting in a generally smoother transition zone between 70 and $10 \mathrm{~m}$, but the subsurface thermocline re-appeared as the winds freshened on 30 July. The salinity profiles, on the other hand, were quite similar below $25 \mathrm{~m}$ throughout the cruise and at the surface, the main variation being the depth of the halocline which moved down around 26 July when the westerly winds began to slacken and rose on 30 July when the wind began to strengthen again. Salinities of 21-23 PSU at the surface were rather lower than had been recorded 2 years previously (KATTEX I) but the deep water, at just over 34 PSU, was little different. The density profiles showed a smooth but quite steep increase from the surface to a depth of $20 \mathrm{~m}$, but only a gentle gradient below that; as with the halocline, the pycnocline dipped around 26 July and rose again by 30 July.

The measurements made on KATTEX III again agree with previous observations that oxygen concentrations are consistently at or near saturation in the surface and middle layers. At $80-100 \mathrm{~m}$ depth within the Alkor 
Temperature $\left({ }^{\circ} \mathrm{C}\right)$

Salinity (PSU)

Density ( $\sigma \mathrm{t})$
$22 / 7 / 98$
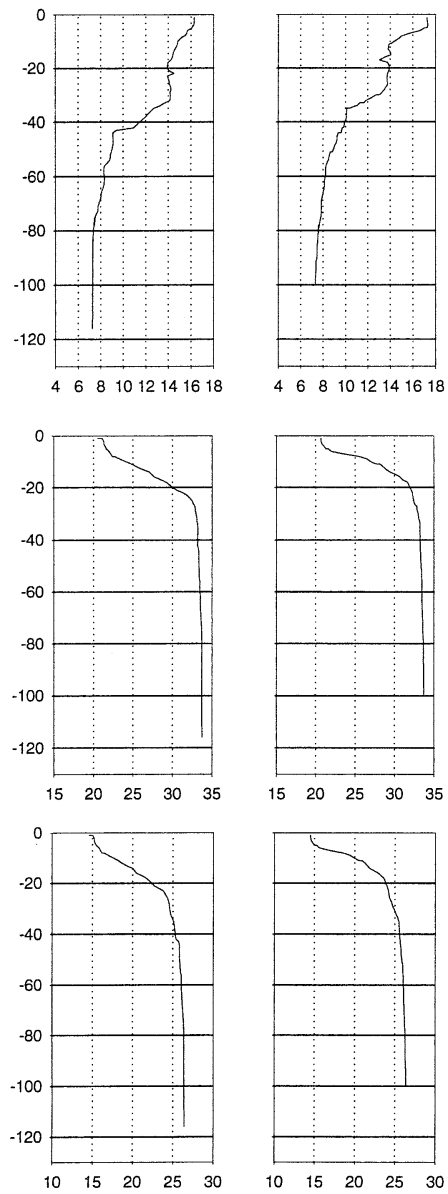

$26 / 7 / 98$
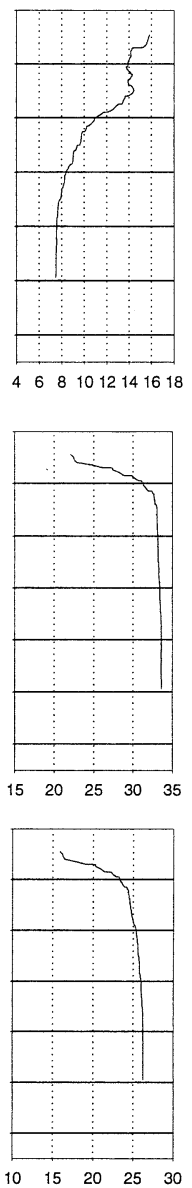

$30 / 7 / 98$
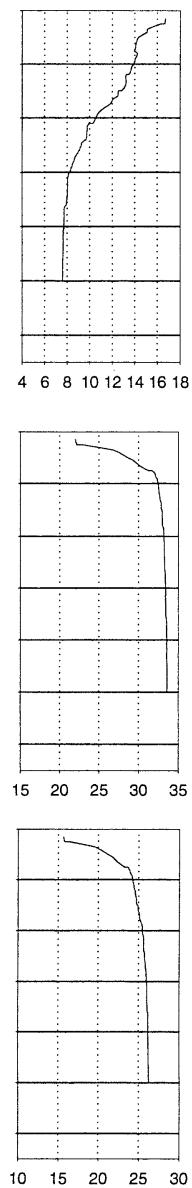

$1 / 8 / 98$

$3 / 8 / 98$
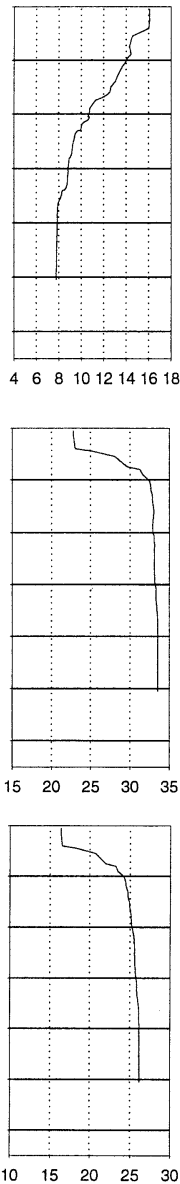

Fig. 11 Temperature, salinity and density profiles in the Alkor Deep during KATTEX III

Deep, however, they were severely depressed, to $51 \%$ saturation. This is the lowest level ever recorded in the Alkor Deep, and observations elsewhere (Strömberg, personal communication) suggest that it would affect the behaviour and the vertical distribution of M. norvegica.

The 23-h series of current measurements (Fig. 12) shows a marked change in the current system at the surface which correlates well with the wind. Deeper, at 48, 80 and even $96 \mathrm{~m}$, the periodic reversal of the current seems to have been associated with the tidal cycle.

\section{Kattegat discussion}

Overall, surface currents were strong and predominantly to the north throughout each sampling period, corresponding to the brackish Baltic outflow, though the strength and even the direction could be affected by strong winds, such that the Baltic Current could vary considerably from day to day, with a variable entrainment effect on the water flowing in from the Skagerrak. Seasonally, the flow of the Baltic Current is likely to be generally retarded by a northerly current in summer and by a westerly one in winter. Bottom currents were predominantly to the south and corresponded to the marine inflow from the Skagerrak. Greater variability of the bottom current in the winter may also have been a result of increased mixing between layers during the winter months. Currents in the intermediate layer were variable, influenced by tidal pressures and reflecting the interaction between opposing current systems above and below. The relatively strong current measurements indicate that the observed hydrographic discontinuities are largely the results of near-horizontal advection of opposing current systems, with some vertical mixing induced by weather conditions near the surface and by current shear.

There are two possible explanations for the remarkably low oxygen values within the Alkor Deep in July 1998: that they were generated in situ, in which case the basin water can be supposed to have been static for a period of time consistent with the local biological oxygen demand, certainly a matter of months; or alternatively that they resulted from the inflow of water from the Skagerrak already depleted in oxygen. Data kindly provided by the Nordsøcenter at Hirtshals, Denmark, and by Flødevigen Biologiske Stasjon, Arendal, Norway, indicate that, although there was no widespread oxygen de- 


品 品

$16 \mathrm{~m}$

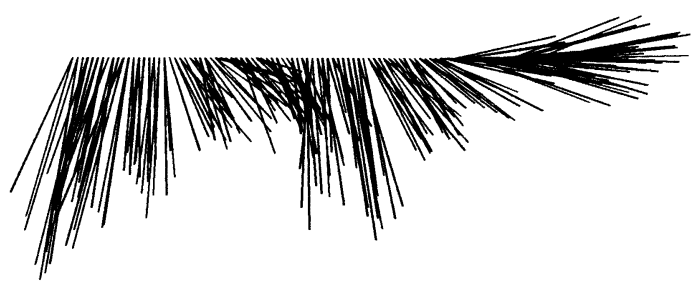

$48 \mathrm{~m}$

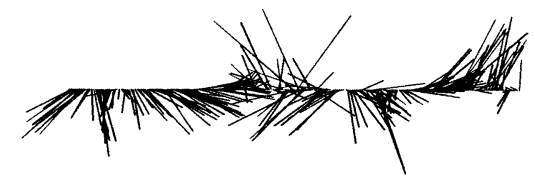

$80 \mathrm{~m}$

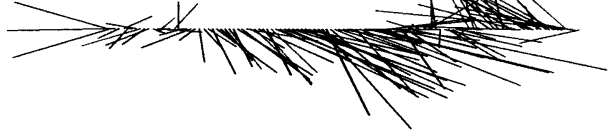

$96 \mathrm{~m}$
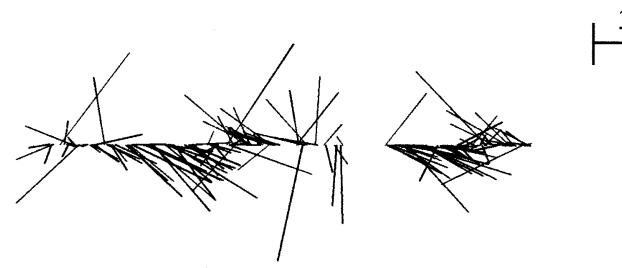

$30 \mathrm{~cm} / \mathrm{s}$

\begin{tabular}{|c|c|c|c|c|c|}
\hline $\begin{array}{l}\text { 웅 } \\
\dot{ }\end{array}$ & $\stackrel{8}{0}$ & \& & & & \\
\hline
\end{tabular}

Fig. 12 Current speed and direction at four depths in the Alkor Deep during KATTEX III (21-22 July 1998)

pletion in the Skagerrak/Kattegat area, values as low as 3-4 $\mathrm{mg} \mathrm{O}_{2}$ (50-60\% saturation), in water at $12^{\circ} \mathrm{C}$ and 33 PSU were obtained off Hirtshals on 12 June, and as low as $4-5 \mathrm{mg} \mathrm{O}_{2}$ (approximately $60 \%$ saturation), in water at $11-14^{\circ} \mathrm{C}$ and $33-34$ PSU; oxygen levels had been replenished to near-saturation by 3 August (G. Frtebjerg, D. Danielssen, personal communication). It seems probable that water from the North Sea can reach the Alkor Deep in a matter of days after passing the tip of Jutland and, moreover, that residence time in the Alkor Deep is similarly brief, since the oxygen deficiency apparently generated in the Skagerrak was no less marked in the Alkor Deep. Possible consequences for the integrity of the population of $M$. norvegica found in and near the Alkor Deep, will be discussed elsewhere in a biological context.

Another important hydrographic influence on the behaviour of M. norvegica is the nature of the boundary of water masses between which it migrates (Buchholz et al.

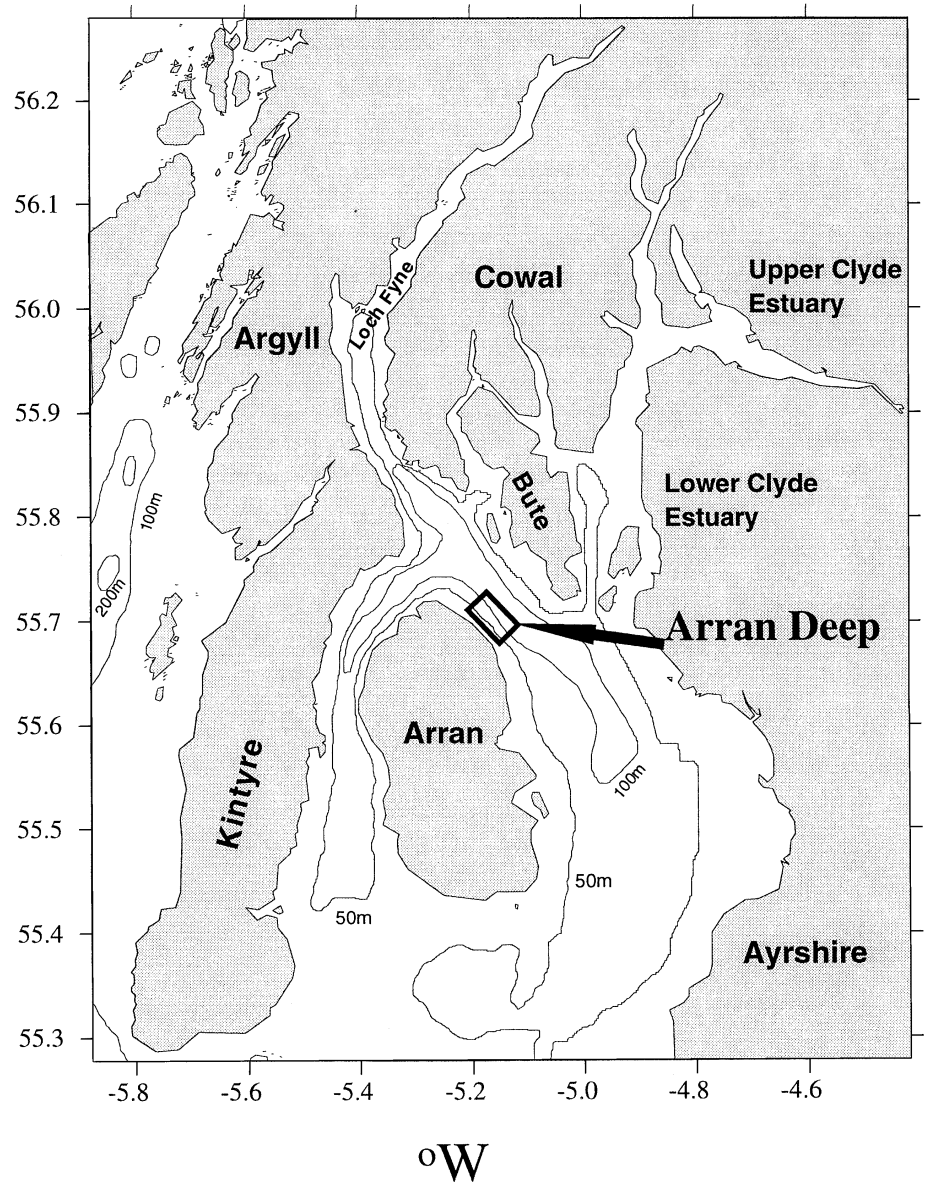

Fig. 13 Map of the Clyde Sea area, showing the main sampling site in the Arran Deep

1995). Apart from temperature and salinity values beyond its tolerance limits, which will be considered in other papers dealing with the physiology and behaviour of the species, the nature of the boundary can be expected to influence the extent and perhaps also the speed of vertical migration. It should be noted that short-term meteorological conditions can strongly change the depth and the sharpness of the thermocline and/or the halocline, and hence the pycnocline, within a few days, e.g. $3 \sigma \mathrm{t}$ over $50 \mathrm{~m}$ on 15 July to 6 ot over $30 \mathrm{~m}$ on 24 July 1996, from 2 ot over $60 \mathrm{~m}$ on 8 March to 6 ot over $15 \mathrm{~m}$ on 18 March 1997; even when the pycnocline profile was little changed, its depth could change significantly, from a maximum gradient at $15 \mathrm{~m}$ on 26 July to $8 \mathrm{~m}$ on 30 July 1998.

\section{Clyde Sea area}

The Firth of Clyde (Fig. 13) is the largest fjord system in Scotland and can be divided into two primary components:

1. The inner parts comprising the upper and lower Clyde Estuary and the fjordic sea lochs, all of which are 

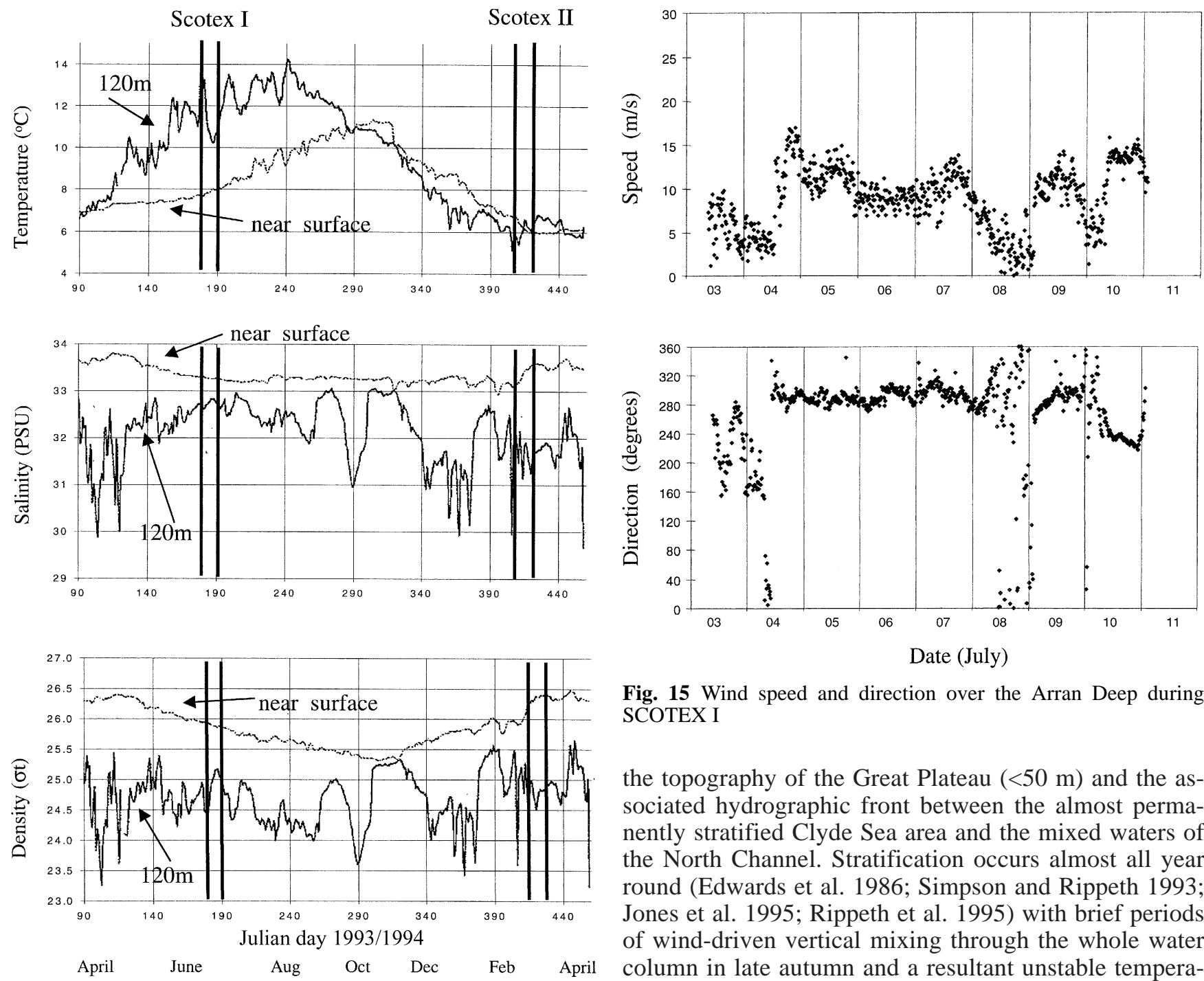

Fig. 14 Time series of temperature, salinity and density in the Arran Deep in 1993-94 (from Rippeth et al 1995)

more or less heavily influenced by freshwater outflow, in consequence of which they show estuarine (fjordic) circulation patterns. Apart from brief excursions into the southern part of Loch Fyne, no PEP investigations have been carried out in this part, so it will not be considered further in this paper.

2. The outer firth with a wide but relatively shallow opening to the North Channel which links the Irish Sea with the northeast Atlantic off the Scottish coast. Consequently, it has the features of a semi-enclosed coastal sea, influenced by ocean climate, tides, the weather, and by fresh water from the Clyde Estuary, the sealochs and the rivers of Ayrshire. PEP investigations have been carried out in this, the Clyde Sea area.

The physical oceanography of the Clyde Sea area has been studied and reviewed most recently by Edwards et al. (1986) and Rippeth et al. (1995). Water movements are influenced by conditions in the hydrographically energetic North Channel, but modulated and constrained by

Fig. 15 Wind speed and direction over the Arran Deep during SCOTEX I

the topography of the Great Plateau $(<50 \mathrm{~m})$ and the associated hydrographic front between the almost permanently stratified Clyde Sea area and the mixed waters of the North Channel. Stratification occurs almost all year round (Edwards et al. 1986; Simpson and Rippeth 1993; Jones et al. 1995; Rippeth et al. 1995) with brief periods of wind-driven vertical mixing through the whole water column in late autumn and a resultant unstable temperature inversion. Strong tides, freshwater outflow, mainly from the Clyde Estuary (Poodle 1986), wind conditions, and the Island of Arran in its northern part all affect the hydrographic conditions and water circulation. The salient features appear to be:

1. An anticyclonic residual circulation in the upper layers around Arran with a speed of about $1-2 \mathrm{~cm} \cdot \mathrm{s}^{-1}$;

2. Stable stratification throughout the summer (May to October) when there is exchange of surface water over the Great Plateau but stagnation of deeper water in the Arran Deep and elsewhere, though oxygen never becomes seriously depleted (Rippeth and Jones 1997);

3. Renewal of deep water in the winter months (November to April) when oceanic water spills over the Great Plateau driven by density gradients (cooler and/or saltier Atlantic water) with residence times of a few weeks to a couple of months;

4. Considerable surface displacement of surface water (up to $15 \mathrm{~km}$ day $^{-1}$ according to Dooley 1979) during windy conditions, with a subsurface counterflow; the prevailing wind direction is from the southwest. 


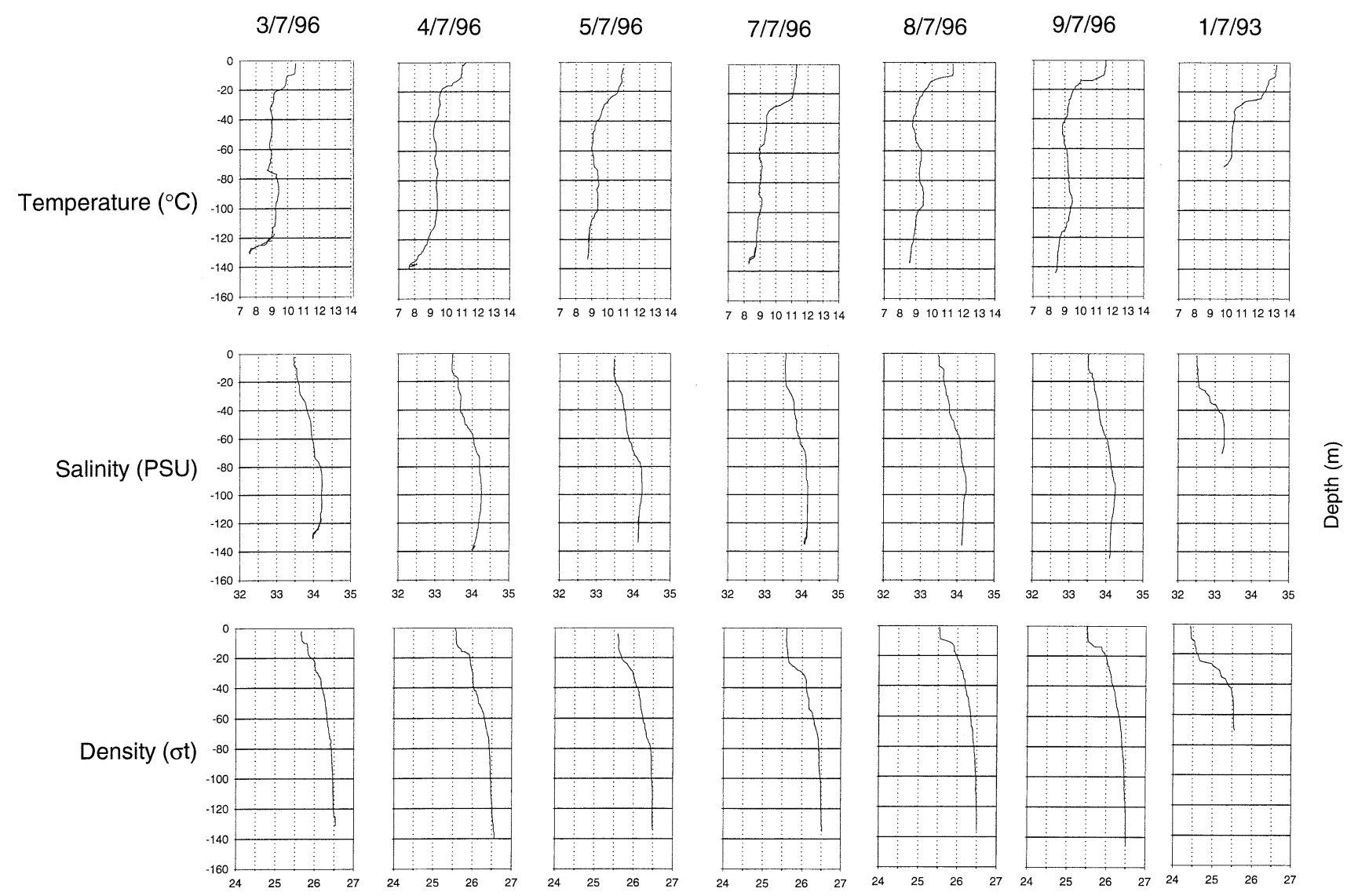

Fig. 16 Temperature, salinity and density profiles in the Arran Deep during SCOTEX I

Rippeth et al. (1995) obtained year-round temperature, salinity and density data for a station to the northeast of Arran close to the PEP sampling site. Their data are presented again in Fig. 14, with vertical lines superimposed to indicate the times of year when corresponding observations were made during SCOTEX I and II.

\section{SCOTEX I, 3-10 July 1996}

Wind records are shown in Fig. 15. After a fairly calm start, the wind freshened to $12-16 \mathrm{~m} \cdot \mathrm{s}^{-1}$ on the second day and remained strong for 3 days, blowing quite consistently from the southwest. Winds were light and variable on 8 July, freshened for a day on 9 July, dropped that night and freshened again at the end of the cruise.

Temperature, salinity and density profiles obtained during SCOTEX I are shown in Fig. 16, alongside the profiles obtained on 1 September 1993 by Rippeth et al. (1995), also available on CD-ROM (Pirate: PROFILE, 1997).

There was a more or less well-defined thermocline at about $20 \mathrm{~m}$ depth throughout the cruise but particularly towards the end. The surface mixed layer was close to $11^{\circ} \mathrm{C}$ throughout the cruise. Below the thermocline, to a depth of $100-120 \mathrm{~m}$, the water column was almost isothermal at $9-9 \cdot 5^{\circ} \mathrm{C}$. Cooler water, $<8^{\circ} \mathrm{C}$, was evident below $120 \mathrm{~m}$ early in the cruise but the temperature gradient was more even towards the end. These values were considerably lower and the thermocline deeper than they had been in July 1993, when the surface temperature was 13.2 and $10.4^{\circ} \mathrm{C}$ throughout most of the deeper water, never dropping below $10^{\circ} \mathrm{C}$, and the main thermocline was at around $25 \mathrm{~m}$.

Although the halocline was less pronounced than the thermocline, the warm surface water had a salinity of ca. 32.5 PSU, while salinity below that gradually increased to 34.2 PSU at $80-100 \mathrm{~m}$. In the colder water recorded on 3 and 4 July below $100 \mathrm{~m}$, there was some sign of decreasing salinity again, suggesting the persistence of a body of water of coastal origin that had entered during colder months. The density profile showed a deepening pycnocline in the surface layer, with wellmixed water above it, coinciding with the stormy weather that persisted from 4 to 7 July. Although the colder, less saline water below $120 \mathrm{~m}$ was less apparent towards the end of the cruise, there was little change in the density of the basin water, suggesting that any deepwater exchange was only weakly driven by a density gradient at this time. By contrast, the surface salinity in July 1993 was only 32.5 PSU, increasing below $10 \mathrm{~m}$ to $33.2 \mathrm{PSU}$ at $40 \mathrm{~m}$ and then more gradually to $33.4 \mathrm{PSU}$ below $70 \mathrm{~m}$. 


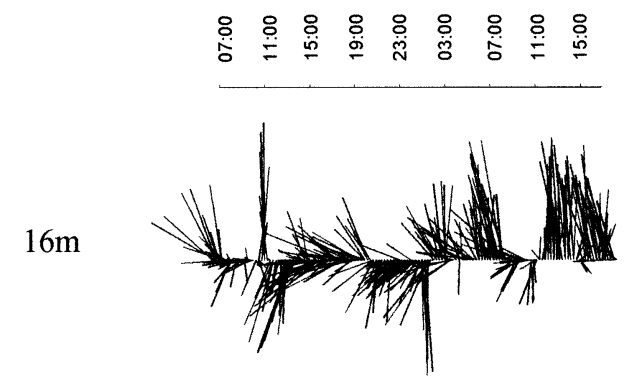

$48 \mathrm{~m}$

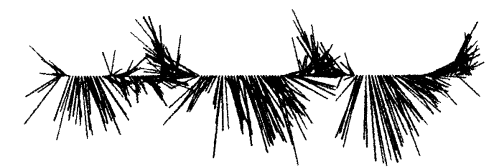

$80 \mathrm{~m}$
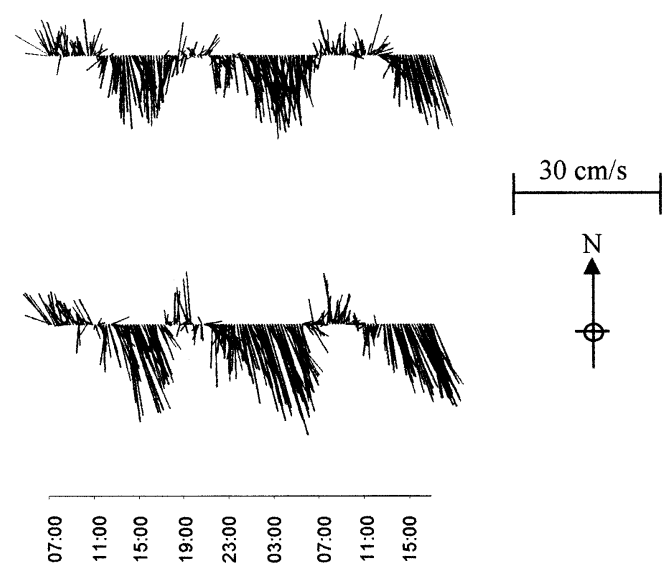

$112 \mathrm{~m}$

Fig. 17 Current speed and direction at four depths over one tidal cycle in the Arran Deep during SCOTEX I (4-5 July 1996)

The density profiles show the effect of these changes over the period of 1 week, how the pycnocline became more pronounced and the surface mixed layer became progressively deeper, before the pycnocline rose again to around $10 \mathrm{~m}$ at the end. In marked contrast, the warmer, less saline water at the surface in July 1993 was much less dense. Density only increased gradually down to the pycnocline at around 25-30 m but continued to increase quite markedly all the way down to $50 \mathrm{~m}$.

Oxygen profiles changed little as measured on 3,6, and 9 July 1996: at the surface, levels were near saturation declining sharply between 20 to $40 \mathrm{~m}$ to approximately $75 \%$ of saturation, apparently associated with the thermocline, with little variation down to $130 \mathrm{~m}$. In the last $20 \mathrm{~m}$ to the bottom, $65 \%$ was found on 3 July but increased to $75 \%$ thereafter.

The main current pattern as discerned by the ADCP in the Arran Deep was associated with the state of the tide and stayed quite consistent throughout the cruise. Results from one tidal cycle during a calm period on
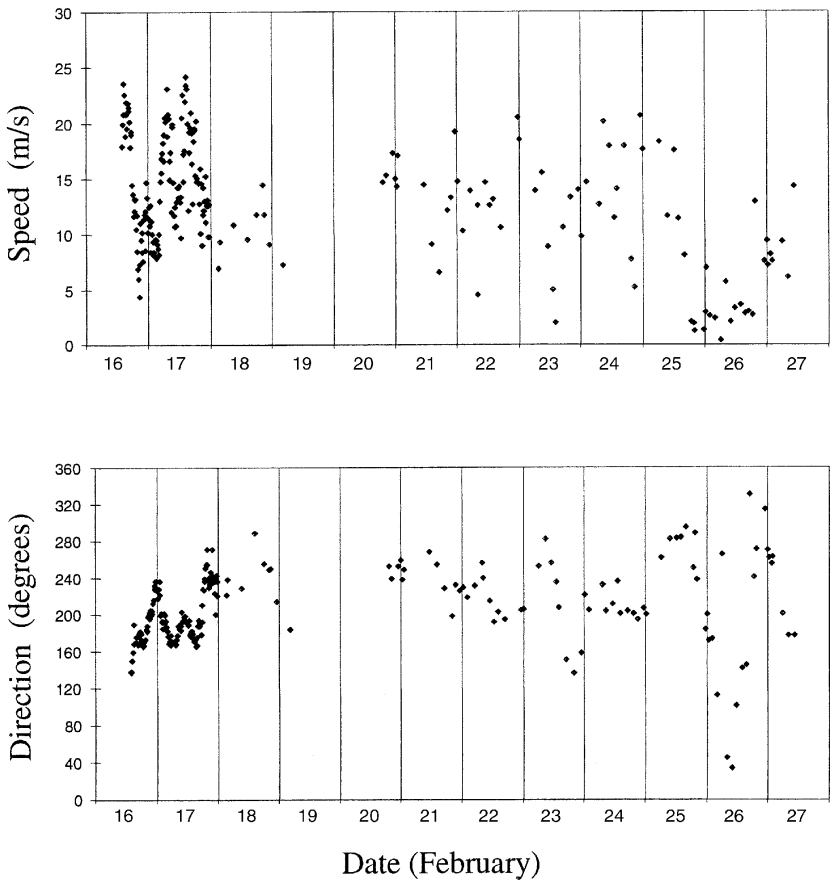

Fig. 18 Wind speed and direction over the Arran Deep during SCOTEX II

4-5. July (Fig. 17) show that flows at all depths were north-northwesterly on the flood and southerly on the ebb. The southerly flow on the ebb was greatest below $100 \mathrm{~m}$ whilst the northerly flow on the flood was most marked in the upper layers.

\section{SCOTEX II, 14-27 February 1997}

Continuous meteorological data are not available after the first 2days of the cruise, but wind data have been recorded at times of sampling (Fig. 18). During the first three-quarters of the cruise, winds were rarely below 10 $\mathrm{m} \cdot \mathrm{s}^{-1}$ and sometimes reached $20 \mathrm{~m} \cdot \mathrm{s}^{-1}$ or more. Except for a relatively calm day on 26 February, when the wind was quite variable, wind blew consistently from the south or southwest.

Temperature, salinity and density profiles are shown in Fig. 19, alongside the profiles obtained on 1 March 1994 by Rippeth et al. (1995), available on CD-ROM (Pirate: PROFILE, Irish Marine Data Centre, 1997). Temperature ranged narrowly from 7.0 to $7.4^{\circ} \mathrm{C}$ and salinity from 33.2 to 33.8 PSU, with transient, low-salinity water appearing at the surface. Although the density gradient was slight, the water column was quite stable at the start but then became thoroughly mixed to a depth of 60 m by 18 February and to $100 \mathrm{~m}$ by 21 February; this coincided with the period of strongest winds. Stability below $60 \mathrm{~m}$ returned quite quickly and a surface layer of cold, low-salinity water was present again on 26 February, almost as soon as the wind had dropped. By contrast, the water column had been almost isothermal and 

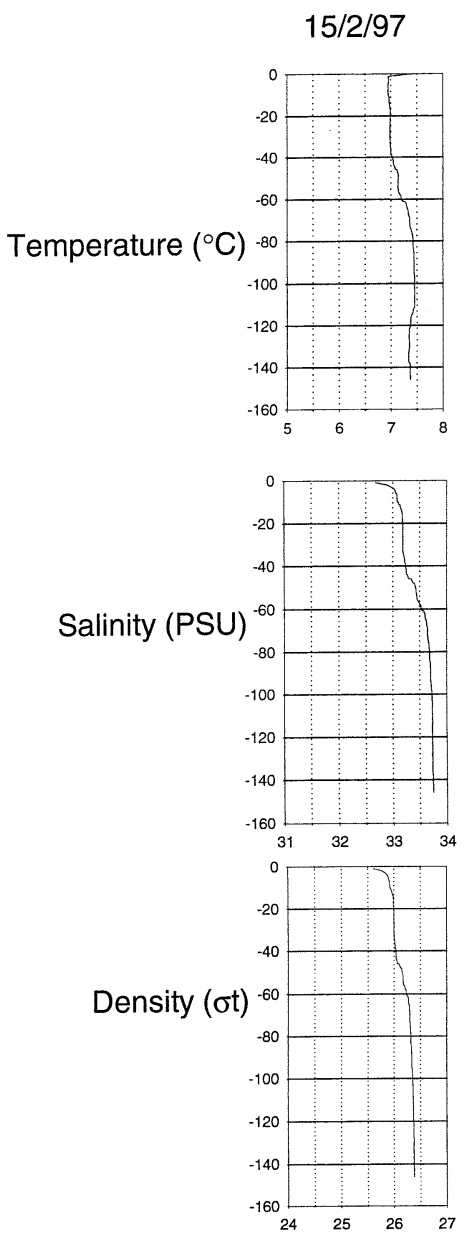
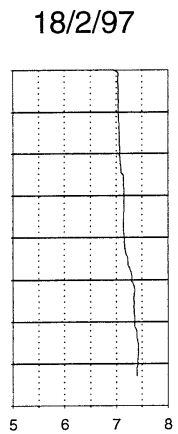

$21 / 2 / 97$
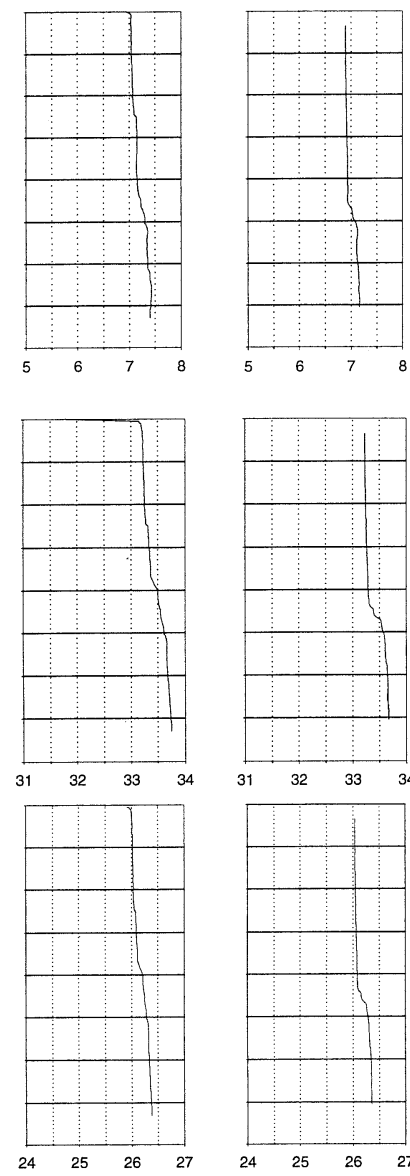
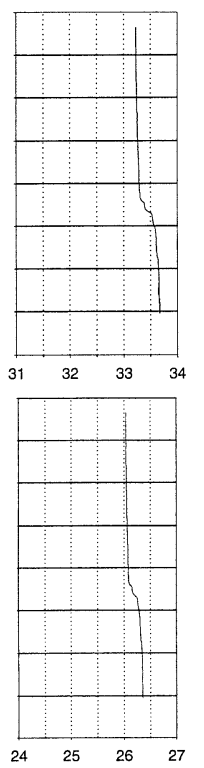
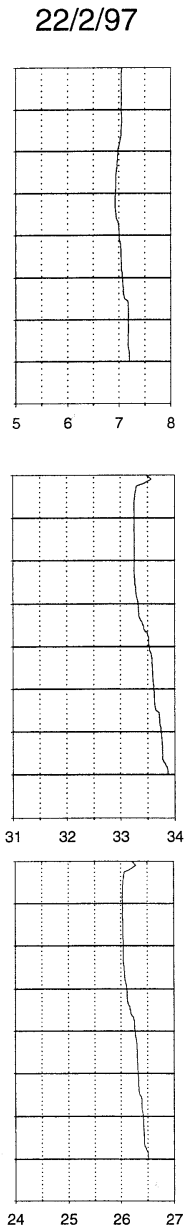
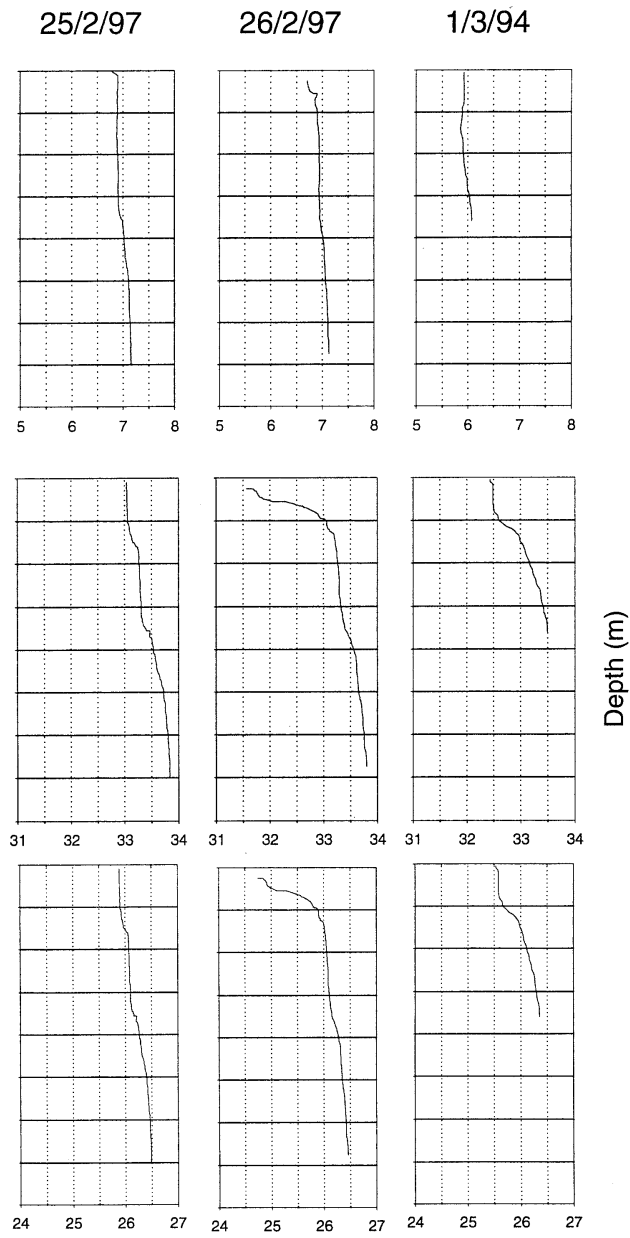

Fig. 19 Temperature, salinity and density profiles in the Arran Deep during SCOTEX II

$1{ }^{\circ} \mathrm{C}$ colder on 1 March 1994 with a gradual increase in salinity from 32.5 PSU near the surface to 33.5 PSU at $70 \mathrm{~m}$, with the greatest increase between 20 and $30 \mathrm{~m}$ producing a pycnocline at this depth. During winter, oxygen saturation was near $100 \%$ from top to bottom.

Figures 20 and 21 show distinct current patterns during a windy and a calm period, respectively. With a strong wind from the southwest, currents at $16 \mathrm{~m}$ were somewhat erratic, predominantly towards the south but with evidence of the tidal cycle. The southerly flow was more marked at $48 \mathrm{~m}$, while at $80 \mathrm{~m}$ the initially strong northerly current gradually declined. Within the Arran Deep, at $112 \mathrm{~m}$, however, there was a strong and consistent flow to the northwest. Under the calmer conditions obtained on 25/26 February, the tidal cycle can be clearly seen near the surface. Currents at intermediate depths were quite changeable, particularly at $48 \mathrm{~m}$, but there was still a consistent northwesterly flow at $112 \mathrm{~m}$, though not as strong as it had been under windy conditions.

\section{Clyde Sea discussion}

The data presented above describe the hydrographic conditions in the Arran Deep during two quite brief periods in the complex seasonal cycle of circulation in the Clyde Sea area, The first period was in midsummer but before temperatures had quite reached their maximum in the surface and quite early in the seasonal warming of the water at intermediate depths. The second period was in the late winter when temperatures were near the seasonal minimum and stratification was least pronounced. Comparison of the summer profiles with those obtained in 1993 indicates a greater input of warmer, fresher water in 1993; density had been notably less down to $60 \mathrm{~m}$ in the earlier year though the pycnocline had been quite marked at $25-30 \mathrm{~m}$. The variability of the profiles almost from day to day, however, emphasize the short-term nature of the fine structure of the water column, in particular the wind-induced surface mixing and the speed of recovery under calmer conditions. The most apparent meteorological changes in the period of observation were the lighter and more variable winds experienced for approximately $24 \mathrm{~h}$ on 3-4 and 8 July and this was reflected almost synchronously by a shallowing and a sharpening of the thermocline, which was reversed just as quickly when the wind freshened. Animals such as M. norvegica migrating into surface layers at night will there- 
$16 \mathrm{~m}$

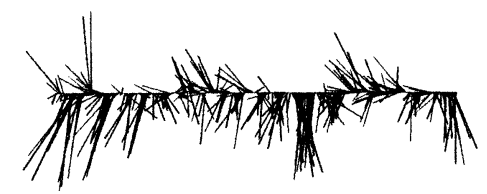

$48 m$

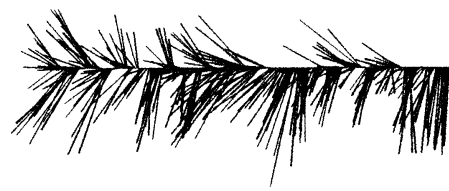

$80 \mathrm{~m}$

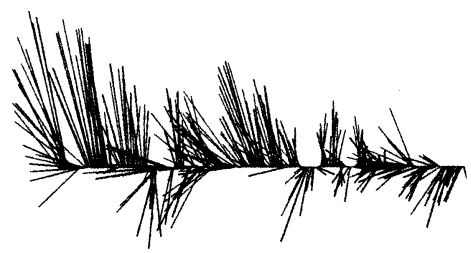

$112 \mathrm{~m}$

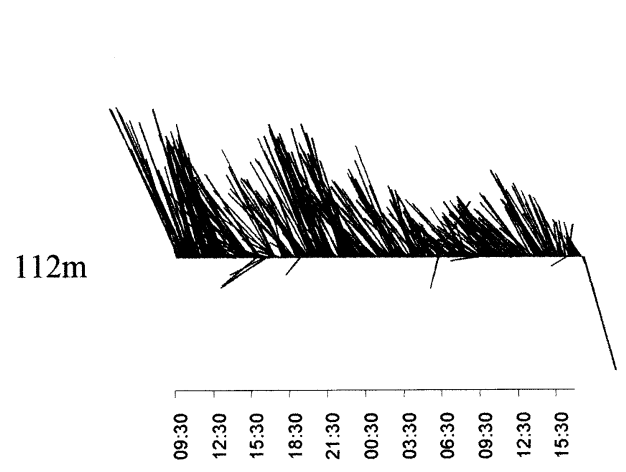

Fig. 20 Current speed and direction at four depths during windy weather in the Arran Deep during SCOTEX II (21-22 February 1997)

fore experience considerable changes from day to day. Like normally in the Kattegat, oxygen levels in the Clyde Sea in summer and winter do not seem to influence distributional patterns in krill to any extent.

The current records shown in Fig. 17 were derived from the period on 4-5 July when the wind increased from $<5 \mathrm{~m} \cdot \mathrm{s}^{-1}$ to about $18 \mathrm{~m} \cdot \mathrm{s}^{-1}$. The ADCP could not provide current data from the surface, but there was little apparent sign of a wind-entrained current at $16 \mathrm{~m}$ depth. At 40 and $80 \mathrm{~m}$ the main signal was tidal, strong, slightly prolonged southerly flow on the ebb tide, apparently weaker northerly currents on the flood tide. The really strong consistent signal came from $112 \mathrm{~m}$, as close to the seabed, at $130 \mathrm{~m}$, that one could obtain reliable data. It is difficult to relate this northwesterly current directly to

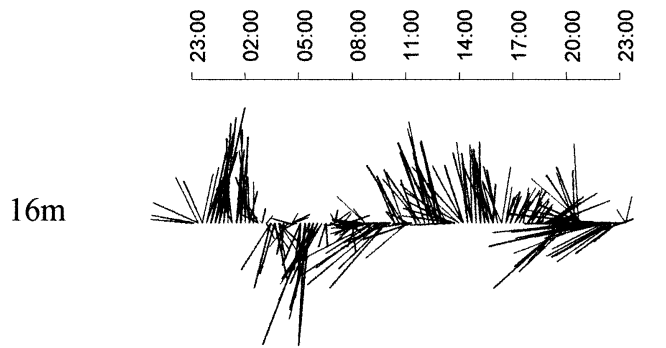

$48 \mathrm{~m}$

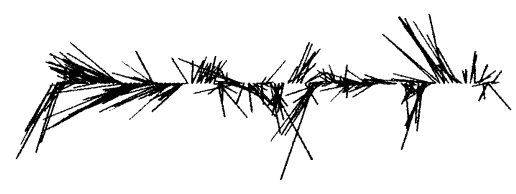

$80 \mathrm{~m}$
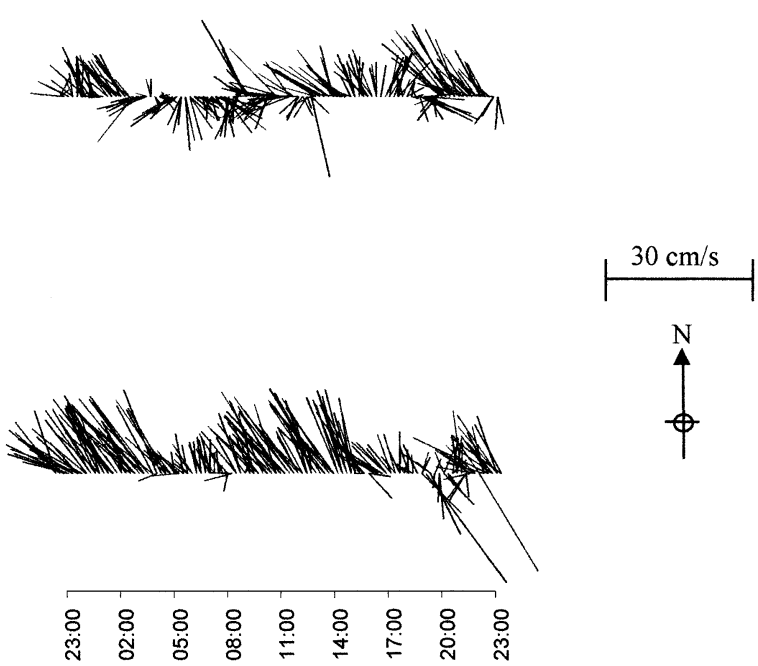

Fig. 21 Current speed and direction at four depths during calm weather in the Arran Deep during SCOTEX II (25-26 February 1997)

the wind which was light and blowing from the northeast to start with before backing to the west and becoming stronger. We conclude that this extensive deep-water flow northwards may indicate a part of the circulation around Arran which may be induced or enhanced by the wind but is not controlled by it.

This conclusion appears to be supported by the current patterns obtained in February 1997, insofar as calm conditions were associated with rather stronger and more consistent deep-water currents, again in a northwesterly direction, than were windy conditions (cf. Figs. 21 and 20 ), and there was no sign of a contra-flow at depth when the wind stress eased. Tidal oscillations appeared not to extend beyond some $80 \mathrm{~m}$. There are therefore likely to be considerable advective forces acting directionally upon plankton populations in the Arran Deep. The rapid changes in the current flows, both tidal and wind-induced, indicate that vertical mixing must be im- 
portant in determining the hydrographic profiles, not just near the surface, but also between the deeper layers.

A comparison between the years suggests potentially contrary effects of wind and rain, though these may often be meteorologically associated. The lower salinity, indicative of heavy rainfall, enhanced subsurface stratification in 1993, while the windy conditions in 1996/97 served to diminish stratification at the time and to drive surface signals deeper down the water column.

Acknowledgements This paper, indeed the whole PEP project, would not have been possible without the enthusiastic support and hard work of all those involved. Those who took part in the cruises recounted in this paper are E. Albessard, A. Bedo, S. Bröhl, C. Buchholz, J. Cuzin-Roudy, S. Dallot, P. David, K. Grau, O. Guerin-Ancey, M. Hatherell, J.-P. Labat, S. Lass, P. Mayzaud, D. Müller-Navarra, M. Salomon, P. Schumann, E. Seris, D. Taillez, J. Virtue, and P. Virtue. On every cruise, the Captain and the crew of FS Heincke ensured that we obtained the data and the material that we needed. At times in winter, their seamanship steered us safely through storm-force winds. In summer we could enjoy their excellent service under less strenuous conditions. Danke schön. We thank the several oceanographers whom we consulted on matters outside our own scientific competence. Any mistakes and naiveties that remain in this paper are our own responsibility, not theirs. We are pleased to acknowledge the usefulness of the CD produced by the Irish Marine Data Centre, containing hydrographic data obtained in the Clyde Sea area as part of the EU "PROFILE" (MAS2-93-0072-IE). This project, the PEP project, is supported by a substantial grant from the EU MAST III Programme (MAS3CT-0013), which is gratefully acknowledged.

\section{References}

Andersson L, Rydberg L (1993) Exchange of water and nutrients between the Skagerrak and Kattegat. Estuar Coast Shelf Sci 36:159-181

Boysen E, Buchholz F (1984) Meganyctiphanes norvegica in the Kattegat. Studies on the annual development of a pelagic population. Mar Biol 79:195-207

Buchholz F, Boysen-Ennen E (1988) Meganyctiphanes norvegica (Crustacea: Euphausiacea) in the Kattegat: studies on the horizontal distribution in relation to hydrography and zooplankton. Ophelia 29:71-82

Buchholz F, Buchholz C, Reppin J, Fischer J (1995) Diel vertical migrations of Meganyctiphanes norvegica in the Kattegat: comparison of net catches and measurements with Acoustic Doppler Current Profilers. Helgoländer Meeresunters 49:849-866

Danielssen DS, Edler L, Fonselius S, Hernroth L, Ostrowsjki M, Svendsen E, Talpsepp L (1991) Oceanographic variability in Skagerrak/northern Kattegat, May-June, 1990. CM/ICES, C1
Dooley HD (1979) Factors influencing water movements in the Firth of Clyde. Estuar Coast Mar Sci 9:631-641

Edwards A, Baxter MS, Ellett DJ, Martin JHA, Meldrum DT, Griffiths CR (1986) Clyde Sea hydrography. Proc R Soc Edinb 90B:67-83

Gustafsson B, Stigebrandt A (1996). Dynamics of the freshwaterinfluenced surface layers in the Skagerrak. J Sea Res 35:39-53

Jones KJ, Grantham B, Ezzi I, Rippeth T, Simpson J (1995) Physical controls on phytoplankton and nutrient cycles in the Clyde Sea, a fjordic system on the west coast of Scotland. In: Skjoldal HRC, Hopkins C, Erikstad KE, Leinaas HP (eds) Ecology of Fjords and Coastal Waters. Elsevier, Amsterdam, pp 93-104

Pirate: PROFILE, 1997. Pirate: a complete project publishing solution (PROFILE MAS2-CT93-0054). Irish Marine Data Centre, $1 \mathrm{CD}$

Poodle T (1986) Fresh water inflows to the Firth of Clyde. Proc R Soc Edinb 90B:55-66

Rippeth TP, Jones KJ (1997) The seasonal cycle of nitrate in the Clyde Sea. J Mar Syst 12:299-310

Rippeth TP, Midgley RP, Simpson JH (1995) The seasonal cycle of stratification in a Scottish fjord. In: Skjoldal HR, Hopkins C, Erikstad KE, Leinaas HP (eds) Ecology of Fjords and Coastal Waters. Elsevier, Amsterdam, pp 85-92

Simpson JH, Rippeth TP (1993) The Clyde Sea: a model of the seasonal cycle of stratification and mixing. Estuar Coast Shelf Sci 37:129-144

Stigebrandt A (1980) Barotropic and baroclinic response of a semi-enclosed basin to barotropic forcing from the sea. In: Freeland HJ, Farmer DM, Levings CD (eds) Fjord oceanography. NATO Conf Ser IV: Marine sciences. Plenum Press, New York, pp 141-164

Stigebrandt A (1983) A model for the exchange of water and salt between the Baltic and the Skagerrak. J Phys Oceanogr $13: 411-427$

Svansson A (1975) Physical and chemical oceanography of the Skagerrak and the Kattegat. Fisheries Board of Sweden, Institute of Marine Research, Göteborg, Rep No 1

Svansson A (1980) Exchange of water and salt in the Baltic and adjacent seas. Oceanol Acta 3:431-440

Svansson A (1984) Hydrographic features of the Kattegat. Rapp P-v Réun. Cons Perm Int Explor Mer 185:78-90

Ulrich J (1983) Zur Bathymetrie und Topographie der nördlichen Kattegat-Rinne. Meeresforschung 30:61-68

Ulrich J, Eisele A (1993) Die Kattegat-Rinne, Erläuterungen zu einer neuen Tiefenkarte. Dtsch Hydrogr Z 45:15-29

Vetter RAH, Buchholz F (1997) Catalytic properties of two pyruvate kinase isoforms in Nordic krill, Meganyctiphanes norvegica, with respect to seasonal temperature adaptation. Comp Biochem Physiol 116A:1-10

Wiebe PH, Morton AW, Bradley AM, Backus RH, Craddock JE, Barber V, Cowles TJ, Flierl GR (1985) New developments in the MOCNESS, an apparatus for sampling zooplankton and micronekton. Mar Biol 87:313-323

Communicated by H.-D. Franke 